Tennessee

Valley

Authority
Water Management

Chattanooga, Tennessee
TVAWM -- 93/15

June 1993

nf

SEP 14153

OSTI

RESERVOIR MONITORING

MONITORING AND EVALUATION OF AQUATIC RESOURCE HEALTH

AND USE SUITABILITY IN TENNESSEE VALLEY AUTHORITY RESERVOIRS

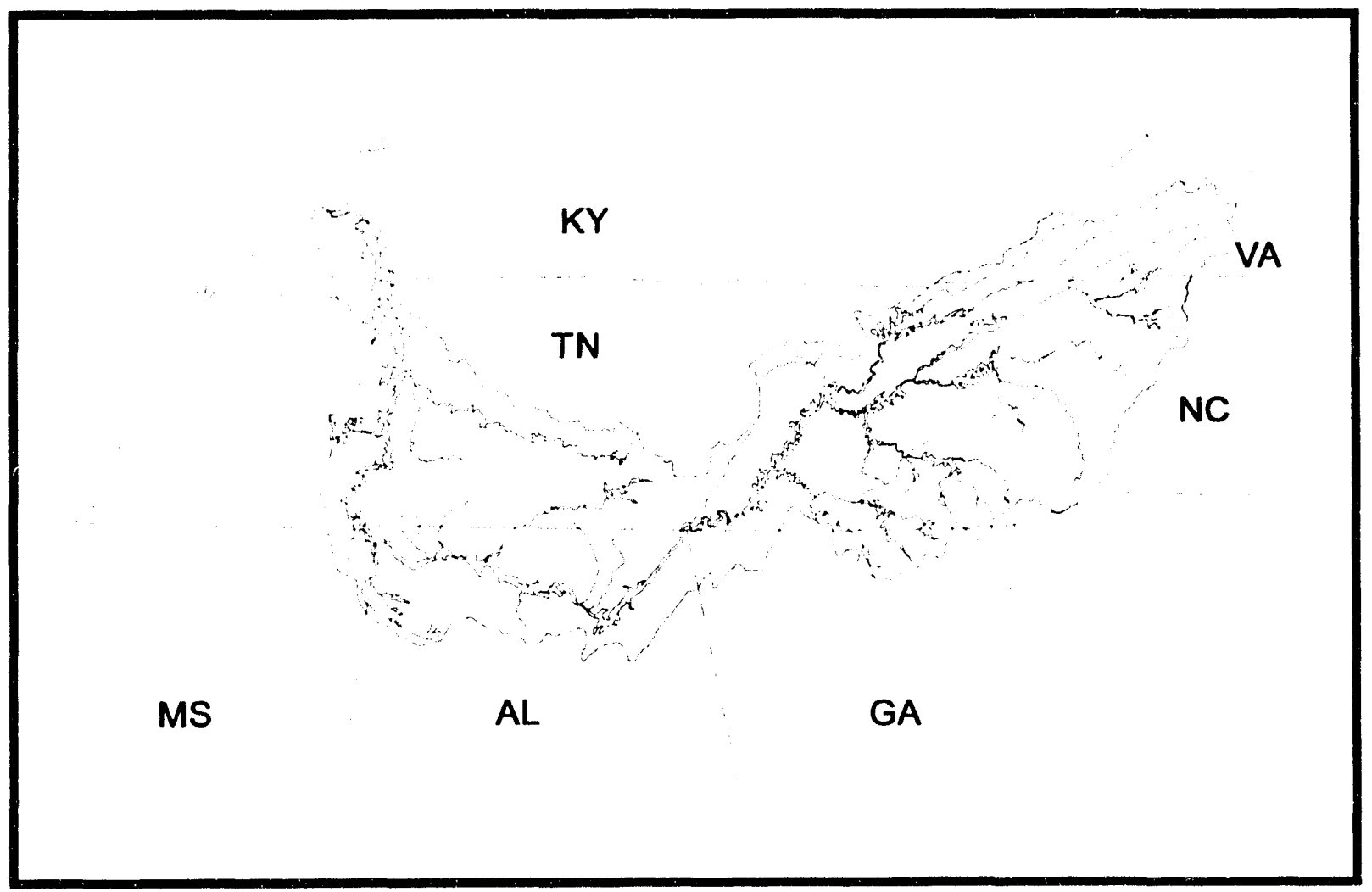

CLEAN WATER INITIATIVE 
TENNESSEE VALLEY AUTHORITY

Resource Group

Water Management

\title{
MONITORING AND EVALUATION OF AQUATIC RESOURCE HEALTH \\ AND USE SUITABILITY IN \\ TENNESSEE VALLEY AUTHORITY RESERVOIRS
}

\author{
Prepared by \\ Donald L. Dycus \\ and \\ Dennis L. Meinert
}

1101 Market Street, HB 2C-C

Chat tanooga, Tennessee 37402

June 1993 


\section{CONTENTS}

1.0 PROGRAM DESCRIPTION . . . . . . . . . . . . . . . . . . . . . . . 1

1.1 Background . . . . . . . . . . . . . . . . . . . . . . 1

1.2 Reservoir Monitoring Objectives . . . . . . . . . . . . . . . . 2

1.3 Reservoir Monitoring Approach and Program Design . . . . . . . 3

2.0 DATA COLLECTION . . . . . . . . . . . . . . . . . . . . . . . 7

2.1 Vital Signs... . . . . . . . . . . . . . . . . . . . . 7

2.1.1 Physical and Chemical Characteristics of Water . . . . . 7

2.1.2 Acute Toxicity Screening and Physical/Chemical

Characteristics of Sediment . . . . . . . . . . . . . 8

2.1.3 Benthic Macroinvertebrate Community Sampling . . . . . . 9

2.1 .4 Fish Community Evaluation . . . . . . . . . . . . . . . 9

2.2 Use Suitability . . . . . . . . . . . . . . . . . . . . . 11

2.2.1 Bacteriological Sampling . . . . . . . . . . . . 11

2.2.2 Fish Tissue Analysis ................. . 11

3.0 RESULTS EVALUATION AND APPLICATION . . . . . . . . . . . . . . . . . 13

3.1 Vital Signs... . . . . . . . . . . . . . . . . . . 13

3.1.1 Dissolved Oxygen (DO) Rating Scheme . . . . . . . . . . 14

3.1.2 Chlorophyll-a Rating Scheme . . . . . . . . . . . . . . 19

3.1.3 Sediment Quality Rating Scheme . . . . . . . . . . . . . 20

3.1.4 Benthic Community Rating Scheme . . . . . . . . . . . . 21

3.1.5 Fish Community Rating Scheme . . . . . . . . . . . . . 24

3.1.6 Overall Reservoir Health Determination . . . . . . . . . 30

3.2 Use Suitability . . . . . . . . . . . . . . . . . . . . 33

3.2.1 Bacteriological Sampling . . . . . . . . . . . . 33

3.2.2 Fish Tissue Studies . . . . . . . . . . . . . . . 34

4.0 REFERENCES . . . . . . . . . . . . . . . . . . . . . . . . . . . . . 37 
1. Schematic of Key Reservoir Sampling Areas . . . . . . . . . . . . . . . 4

2. Time vs. Depth Plots of Dissolved Oxygen Concentrations . . . . . . . . 16

\section{TABLES}

1. Physical/Chemical Measurements - Sediment Reservoir

Vital Signs Monitoring, 1992 . . . . . . . . . . . . . . . . . . . . 10

2. Scoring Criteria for Benthic Macroinvertebrate Metrics . . . . . . . 25

3. Core Fish Species with Trophic, Tolerance, and Reproductive Designations for Use in Preliminary Electrofishing Reservoir Fish Assemblage Index for TVA Reservoirs, 1991 . . . . . . . . . . . 27

4. Reservoir Fish Assemblage Index Metrics and Scoring Criteria Developed for TVA Run-of-the-River and Tributary Reservoirs . . . . . 29

5. Computational Method For Evaluation of Reservoir Health... . . . . . 32

\section{KEY CONTACTS}

$\begin{array}{ll}\frac{\text { Overview }}{\text { Neil Carriker }} & (615) 751-7330 \\ \text { Don Dycus } & (615) 751-7322 \\ \text { Dennis Meinert } & (615) 751-8962 \\ \frac{\text { Dissolved Oxygen }}{\text { Dennis Meinert }} & \\ \frac{\text { Chlorophyll-a }}{\text { Dennis Meinert }} & \\ \frac{\text { Sediment Quality }}{\text { Don Wade }} & \\ \text { Dennis Meinert } & \\ \frac{\text { Benthic Macroinvertebrates }}{\text { Anita Masters }} & \\ \frac{\text { Fish Assemblage }}{\text { Gary Hickman }} & \text { (205) } 386-2068 \\ \text { Bacteriological } & \\ \text { Joe Fehring } & \\ \frac{\text { Fish Tissue }}{\text { Don Dycus }} & \end{array}$


TVA initiated a Reservoir Monitoring Program in 1990 with two objectives-to evaluate the health of the reservoir ecosystem and to examine how well each reservoir meets the swimmable and fishable goals of the Clean water Act. In the first year (1990) reservoir health was evaluated subjectively using a weight-ofevidence approach (a reservoir was deemed healthy if most of the physical, chemical, and biological monitoring components appeared healthy). In the second year (1991) a more objective, quantitative approach was developed using information on five important indicators of reservoir health--dissolved oxygen; chlorophyll, sediment quality, benthic macroinvertebrates, and fishes. The most recent information (1992) was evaluated with the same basic approach, modified to incorporate improvements based on comments from reviewers and additional data. Reservoirs were stratified into two groups for evaluation: run-of-the-river reservoirs and tributary storage reservoirs. Key locations are sampled in each reservoir (forebay, transition zone or midreservoir, inflow, and major embayments) for most or all of these five reservoir health indicators.

For each indicator (or metric), scoring criteria have been developed that assign a score ranging from 1 to 5 representing poor to good conditions, respectively. Scores for the metrics at a location are summed and then the sums for all location are totaled. Each reservoir has one to four sample locations depending on reservoir characteristics. The resultant total is divided by the maximum possible score (all metrics good at all locations) for the reservoir. Thus, the possible range of scores is from 20 percent (all metrics poor) to 100 percent (all metrics good).

This reservoir ecological health evaluation method is proving to be a valuable tool for providing the public with information about the condition of the Valley's reservoirs, for allowing meaningful comparisons among reservoirs, and for tracking changes in reservoir health with time. 


\section{MONITORING AND EVALUATION OF AQUATIC RESOURCE HEALTH \\ AND USE SUITABILITY IN \\ IENNESSEE VALLEY AUTHORITY RESERVOIRS}

\subsection{PROGRAM DESCRIPTION}

\subsection{Background}

The Tennessee Valley Authority (TVA) operates over 40 reservoirs in the Tennessee Valley for a variety of uses. These reservoirs generally fall within two broad categories: run-of-the-river reservoirs with short retention times (less than 30 days) and annual drawdowns of only a few feet; or storage impoundments with long retention times (30-400 days) and large drawdowns (exceeding 100 feet at some projects). Within both categories there are variations in reservoir sizes, hydrologic operational patterns, water quality characteristics, trophic status, land use characteristics, etc. Nearly all the reservoirs are used for water supply, recreation, and flood control, and most of the dams have hydroelectric units that provide an economical source of electricity. In addition, the run-of-the-river reservoirs are used for commercial navigation. TVA manages the reservoir system using funds from federal appropriations and revenues from power sales.

TVA views its stewardship responsibilities for these reservoirs as one of the agency's prime reasons for existence. TVA's Strategic Plan states that one of TVA's prime missions is "to make the Tennessee River the cleanest and most productive commercial river system in the United States by the year $2000 . "$

An important component of the effort to achieve this goal is a comprehensive, integrated water quality monitoring program. TVA's ambient monitoring program is funded by federal appropriations and includes a variety of activities on major tributary streams and reservoirs. The stream monitoring program began in 1986; the systemic reservoir monitoring program began in 1990 , when appropriations were increased for TVA to better fulfill its stewardship responsibilities. 
This document describes TVA's Reservoir Monitoring Program and the techrique used to evaluate the ecological health of each reservoir.

\subsection{Reservoir Monitoring Objectives}

Objectives of the Reservoir Monitoring Program are to provide basic information on the "health" or integrity of the aquatic ecosystem in each TVA reservoir (Vital Signs Monitoring) and to provide screening level information for describing how well each reservoir meets the "fishable" and "swimmable" goals of the Clean Water Act (Use Suitability Monitoring). The basis of Vital Signs Monitoring is examination of appropriate physical, chemical, and biological indicators in important areas of each reservoir. The information is used to evaluate the ecological health of each reservoir and the overall health of the reservoir system, and to target areas where detailed assessment studies are necessary to identify causes of significant problems. In addition, this information establishes a baseline for comparing future water quality conditions and monitoring water quality trends for TVA reservoirs.

Use Suitability Monitoring has two components. One is monitoring levels of toxic contaminants in fillets of important fish species to evaluate suitability for human consumption (fishable). The other component evaluates suitability for swimming and other water contact uses (swimmable) through bacteriological sampling at designated swimming beaches and other popular recreation areas.

Results from this monitoring program are communicated to professionals via annual technical reports and to the public via Riverpulse, a nontechnical document designed to inform the public of the condition of Valley reservoirs and rivers. 


\subsection{Reservoir Monitoring Approach and Program Design}

Four assumptions form.the basis for this monitoring program:

1. It is a long-term program to document the status of the reservoir system and track water quality improvement efforts;

2. It is responsive by providing current information to resource managers;

3. It is dynamic and flexible, rather than rigid and static, and will adopt new techniques of environmental monitoring as they develop to meet specific needs;

4. It is a monitoring program; as such it does not address cause/effect mechanisms. (The step beyond monitoring is assessment in which cause/effect investigations would target specific, identified concerns.)

In designing a program to meet these objectives, consideration was given to important reservoir areas (inflow area, transition zone, forebay, overbanks, and embayments), important water resource elements (physical, chemical, and biological), and frequency of examination. The program that emerged was a balance of all these considerations.

Three reservoirs areas were selected for monitoring--the inflow area, generally riverine in nature; the transition zone or midreservoir area where water velocity decreases due to increased cross-sectional area, suspended materials begin to settle, and primary productivity increases due to increased water clarity; and the forebay, the lacustrine area near the dam (figure 1). Overbanks, basically the floodplain which was inundated when the dam was built, are included in transition zone and forebay areas.

Monitoring in all embayments is beyond the scope of this program. There are too many embayments on TVA reservoirs for monitoring to be cost/effective, and previous studies have shown they are mostly controlled by activities and characteristics within their own watersheds, usually with relatively little 


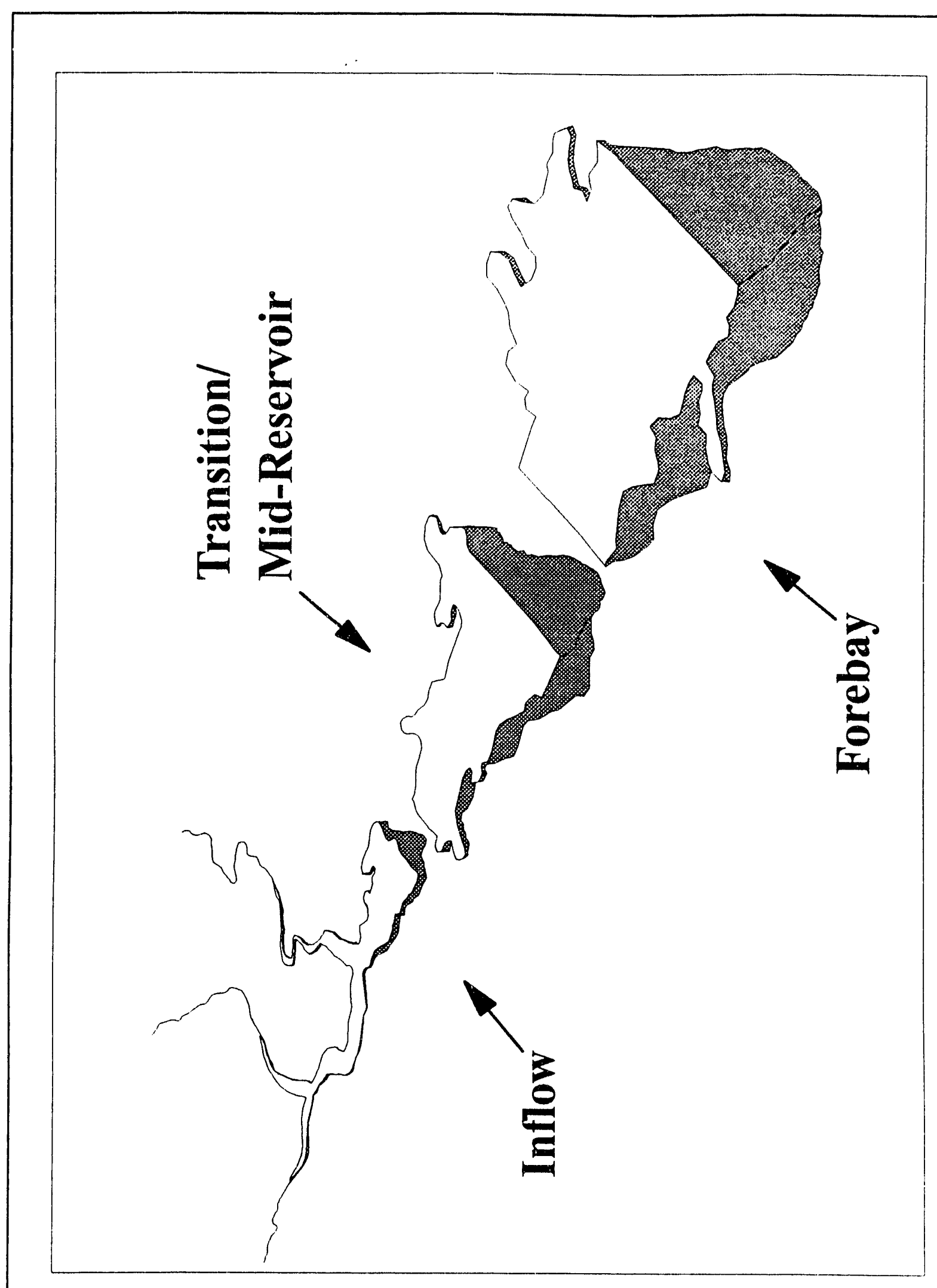



ป 
influence from the main body of the reservoir. As a result, only four embayments, all with surface areas over 5000 acres, are included in the Vital Signs Monitoring Program.

Selection of resource elements (or appropriate indicators) for monitoring was tailored to the specific objective and type of monitoring location. For Vital Signs Monjtoring (reservoir health), physical, chemical, and biological information was deemed essential. Indicators were selected to provide information from various habitats or ecological compartments within a sample area to evaluate the health for the particular habitat or compartment (figure 1). The open water, pelagic area was represented by physical and chemical characteristics of water (including chlorophyll) in midchannel. The shoreline or littoral area was evaluated by sampling the fish community. The bottom, benthic compartment was evaluated using two indicators: quality of surface sediments in midchannel (determined by chemical analysis of sediments and acute toxicity testing of pore water); and examination of benthic macroinvertebrates from a transect across the full width of the sample area (including overbank- if present). Information from each of these indicators was evaluated separately and then combined (without weighing) to arrive at an overall evaluation of reservoir ecological health. (Further description of the reservoir evaluation and scoring process is provided in section 3.1 ).

Monitoring for Use Suitability objectives was limited to bacteriological examination of swimming areas to address the swimmable goal and to analysis of fish tissue contamination for the fishable goal. 


\subsection{DATA COLLECTION}

\subsection{Vital Signs}

\subsubsection{Physical and Chemical Characteristics of Water}

Physical/chemical water quality monituring activities follow either a

"basic" or "limited" sampling strategy, depending upon reservoir type.

Basic--Monitoring on the run-of-the-river reservoirs follows the basic sampling strategy. This includes monthly water quality surveys (April through September) at forebays and transition zones. Basic monthly water quality sampling includes in situ water column measurements of temperature, dissolved oxygen, $\mathrm{pH}$, and conductivity; Secchi depth measurements; surface fecal coliform; photic zone composite chlorophyll-a samples; and surface composite and nearbottom samples for nutrient; (organic nitrogen, ammonia nitrogen, nitrate+nitrite nitrogen, total phosphorus, and dissolved orthophosphorus), total organic carbon, color, and suspended solids. Physical/chemical water quality sampling is not conducted at most run-of-river reservoir inflows because most of these locations are tailwater areas of upstream dams, and water quality characteristics would be representative of processes in the upstream reservoir.

Limited--The limited sampling strategy is conducted on tributary storage reservoirs with monthly (April through October) water quality sampling for a smaller list of parameters. The limited water quality sampling is the same as the basic water quality sampling, except that no fecal coliform, color, or suspended solids samples are collected, and nutrients and organic carbon samples are collected only in April and August. The April and August nutrient samplings are designed to provide information on nutrient concentrations available at the beginning of the growing season, then near the end of the growing season. Forebays are sampled on all these reservoirs, and midreservoir locations are sampled on all but the smaller reservoirs. 
Physical/chemical water quality data are stored on EPA's water quality data storage and retrieval (STORET) system.

\section{$2.1 .2 \frac{\text { Acute Toxicity Screening and Physical/Chemical Characteristics }}{\text { of Sediment }}$}

Annual sediment samples and near-bottom water samples are collected during summer from the forebays and transition zones. Eckman dredge samplers are used to collect the top three centimeters of sediment from at least three locations along a transect in the old river bed (i.e., the deepest part of the reservoir, where active deposition is occurring). Sediment from the three (or more) locations is composited, thoroughly mixed, and split for acute toxicity testing and physical/chemical analysis. Kemmerer or Isco water samplers are used to collect near-bottom water.

Acute Toxicity--Sediment pore water and near-bottom water samples are screened for toxicity using acute time-frame Microtox (light emitting bacteria) and $\operatorname{Rotox}^{\circ}$ (rotifer survival) tests. Microtox ${ }^{\bullet}$ analyses evaluate the effective concentration in laboratory duplicate samples at which light output is reduced relative to a control. The effective concentration used is the $\mathrm{EC}_{10}$, which is the concentration at which light emission in the samples is reduced by 10 percent. Although Microtox $\mathrm{EC}_{10}$ values have been shown to correspond with impairments to insect populations, use here is considered experimental. For this reason, Microtox ${ }^{\bullet}$ results are not interpreted as a definitive, stand-alone analysis, and Rotox testing is also conducted. Rotifer acute (24-hour) toxicity is reported if the average survival in three replicates is significantly reduced from controls. Rotox ${ }^{\bullet}$ and Microtox ${ }^{\bullet}$ results are used in conjunction to describe toxicity. In subsequent years, Microtox tests will be replaced with an acute Ceriodaphnia test. 
Physical/Chemical Characteristics--Sediment samples are also analyzed for 12 metals, total and volatile solids, particle size, and 26 selected trace organics (table 1).

\subsubsection{Benthic Macroinvertebrate Community Sampling}

Benthic macroinvertebrate community samples are collected in spring from forebays, transition zones, and inflows of most run-of-the-river reservoirs. At each sample location, a line-of-sight transect is istablished across the width of the reservoir, and ten equally spaced Ponar grab samples are collected along this transect. When rocky substrates are encountered, a Peterson dredge is used. Specimens are sorted, countrd, and identified to the lowest practical taxon, typically genus or species, and reported as number per square meter.

\subsubsection{Fish Community Evaluation}

Data from autumn electrofishing and gill netting are used to evaluate the fish community at forebays, transition zones, and inflows of most run-of-theriver reservoirs. Similar information is also collected from forebays and most midreservoir locations on tributary reservoirs. Ten electrofishing runs are made at each location, with all habitats sampled, and dominant habitats receiving the most effort. Habitat distinctions are based on major changes in substrate (e.g., bluff, rip-rap, or clay) and/or presence of cover such as brush or boat docks. Twelve experimerical gill nets are also set overnight at each location in all habitat types where conditions permit. At some inflow locations, flow and/or lack of sui-able sites limit the number of nets that can be set. All fish collected from both electrofishing and gill netting are enumerated, with length and weight measurements taken on several important sport species. Largemouth bass collected as part of the electrofishing survey are transported to a mobile laboratory for immediate examination of external/internal abnormalities and olood 
Table 1. Physical/Chemical Measurements (dry weight) - Sediment Reservoir Vital Signs Monitoring, 1992

Description, units

Aluminum, mg/g

Cadmium, mg/kg

Calcium, mg/g

Chromium, mg/kg

Copper, $\mathrm{mg} / \mathrm{kg}$

Iron, $\mathrm{mg} / \mathrm{g}$

Lead, $\mathrm{mg} / \mathrm{kg}$

Magnesium, mg/g

Manganese, mg/g

Mercury, mg/kg

$\mathrm{Nickel}, \mathrm{mg} / \mathrm{kg}$

$\mathrm{Zinc}, \mathrm{mg} / \mathrm{kg}$

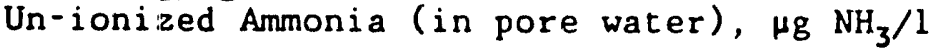

Solids

Total solids, \%

Total volatile solids, $\%$

Particle size, $<0.062 \mathrm{~mm}$ diameter, $\%$

Particle size, <0.125 mm diameter, \%

Particle size, $<0.50 \mathrm{~mm}$ diameter, $\%$

Particle size, $<2.0 \mathrm{~mm}$ diameter, $\%$

Sediment Quality Guidelines

Metals and Ammonia

$1 \mathrm{mg} / \mathrm{g}$

$0.5 \mathrm{mg} / \mathrm{kg}$

$0.5 \mathrm{mg} / \mathrm{g}$

$10 \mathrm{mg} / \mathrm{kg}$

$2 \mathrm{mg} / \mathrm{kg}$

$1 \mathrm{mg} / \mathrm{g}$

$5 \mathrm{mg} / \mathrm{kg}$

$0.5 \mathrm{mg} / \mathrm{g}$

$0.1 \mathrm{mg} / \mathrm{g}$

$0.1 \mathrm{mg} / \mathrm{kg}$

$5 \mathrm{mg} / \mathrm{kg}$

$10 \mathrm{mg} / \mathrm{kg}$

$10 \mu \mathrm{g} / 1$
$-$

$6 \mathrm{mg} / \mathrm{kg}$

-.

$75 \mathrm{mg} / \mathrm{kg}$

$50 \mathrm{mg} / \mathrm{kg}$

$-$.

$60 \mathrm{mg} / \mathrm{kg}$

-.

-

$1 \mathrm{mg} / \mathrm{kg}$ $50 \mathrm{mg} / \mathrm{kg}$ $200 \mathrm{mg} / \mathrm{kg}$ $200 \mu \mathrm{g} / 1$

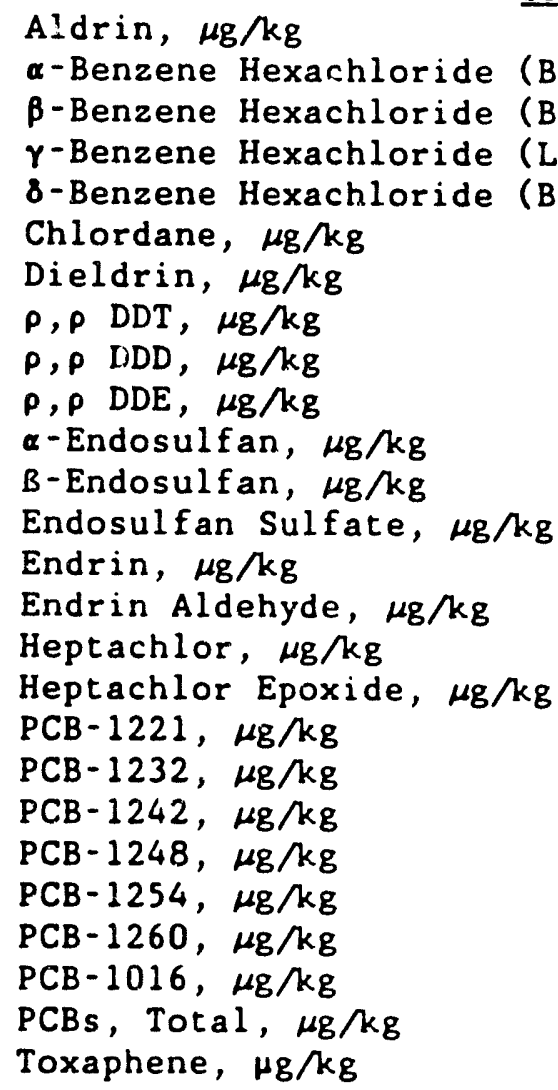
$0.1 \%$
$0.1 \%$
$0.1 \%$
$0.1 \%$
$0.1 \%$
$0.1 \%$

- -

$-$

$-$

-

-

-.

$10 \mu \mathrm{g} / \mathrm{kg}$

$10 \mu \mathrm{g} / \mathrm{kg}$

$10 \mu g / \mathrm{kg}$

$10 \mu g / \mathrm{kg}$

$10 \mu g / \mathrm{kg}$

$10 \mu g / \mathrm{kg}$

$10 \mu \mathrm{g} / \mathrm{kg}$

$10 \mu g / \mathrm{kg}$

$10 \mu g / \mathrm{kg}$

$10 \mu \mathrm{g} / \mathrm{kg}$

$10 \mu \mathrm{g} / \mathrm{kg}$

$10 \mu \mathrm{g} / \mathrm{kg}$

$10 \mu \mathrm{g} / \mathrm{kg}$

$10 \mu \mathrm{g} / \mathrm{kg}$

$1000 \mu \mathrm{g} / \mathrm{kg}$

$10 \mu \mathrm{g} / \mathrm{kg}$

$10 \mu g / \mathrm{kg}$

$100 \mu \mathrm{g} / \mathrm{kg}$

$100 \mu \mathrm{g} / \mathrm{kg}$

$100 \mu \mathrm{g} / \mathrm{kg}$

$100 \mu \mathrm{g} / \mathrm{kg}$

$100 \mu \mathrm{g} / \mathrm{kg}$

$100 \mu \mathrm{g} / \mathrm{kg}$

$100 \mu \mathrm{g} / \mathrm{kg}$

$100 \mu g / k g$

$500 \mu \mathrm{g} / \mathrm{kg}$

1 Guidelines for heaw metals are EPA Region V Guidelines for heavily polluted freshwater sediment (EPA, 1977). All other guidelines ore suggested TVA Guidelines. 
chemistry characteristics. At each sampling location, 15 individuals greater than $250 \mathrm{~mm}$ total length are examined and a Fish Health Assessment Index (FHAI) is calculated.

\subsection{Use Suitability}

\subsubsection{Bacteriological Sampling}

In 1989, TVA began a program of periodically sampling recreation sites in the Tennessee Valley for fecal coliform bacteria to determine each site's suitability for water contact recreation. In addition to swimming beaches, many other recreation sites are also included in the program, such as canoe launch areas, picnic areas, boat ramps, marinas, etc. The bacteriological samping program includes approximately 260 sites and is designed to sample all locations on a frequency of about once every other year. Prior to 1993, the sampling schedule was approximately every five years.

Samples are collected in a manner to conform with state criteria and federal guidelines, such that at each site at least ten fecal coliform samples are collected within a 30-day sampling period. Recreation sites are classified as fully supporting, partially supporting, or not supporting water contact recreation based on EPA guidelines for fecal coliform bacteria (EPA, 1991).

\section{2 .2 Fish Tissue Analysis}

In cooperation with Valley states, TVA analyzes tissue of Tennessee Valley fish as part of both "screening" and "intensive" evaluations. In screening studies, composited fillets of indicator fish species (primarily channel catfish) are analyzed to identify possible problem areas where intensive investigation may be needed. For intensive studies, individual fillets from important fish species are analyzed to better document the number of species contaminated and level of contamination in each species. More locations are sampled than in screening to define the geographical extent of the contamination. 
The intent is to provide information that state public health officials can use to determine whether fish consumption advisories should be issued to protect human health.

Fish collected for screening studies usually are analyzed for metals, PCBs, and pesticides on EPA's Priority Pollutant List. Fish collected for intensive studies usually are analyzed only for the contaminant of concern. During the preparation process, observations on external and internal conditions of each fish are recorded as well as length, weight, sex, fillet weight, and liver weight. 


\subsection{RESULTS EVALUATION AND APPLICATION}

\subsection{Vital Signs}

The objective of Vital Signs monitoring is to determine the health or integrity of the aquatic ecosystem within each reservoir. There are no official or universally accepted guidelines or criteria upon which to base such an evaluation. Consequently, TVA has developed its own evaluation system for this program. The system uses five aquatic health indicators--dissolved oxygen, chlorophyll-a, sediment quality, benthic macroinvertebrates, and fishes.

A critical step in developing an ecological health evaluation is deciding for each indicator what results represent good conditions and what indicates poor conditions. This is more easily done for evaluation of natural lakes and streams because there usually are essentially unaltered reference sites that can be examined to define "good" conditions for each indicator. Because reservoirs are man-made alterations of natural streams, there are no "reference reservoirs." An alternative approach is required. Of several possible alternative approaches, two were used to develop this evaluation system.

Scoring criteria for the dissolved oxygen and chlorophyll-a indicators were based on what could be considered a conceptual model. This simply means that scoring criteria were developed subjectively, based on several years experience dealing with biological systems in reservoirs. This experience has shown that below a certain minimum level of chlorophyll primary production is not sufficient to maintain an active, biologically healthy system. However, above some threshold level, undesirable conditions occur that indicate eutrophication. Minimum and maximum chlorophyll concentrations were selected using this professional judgment and experience. The concept of dissolved oxygen criteria for a reservoir is quite complicated due to the combined effects of flow regulation and potential for oxygen depletion in the hypolimnion. The scoring criteria described below are an attempt at a multidimensional approach that 
includes consideration of dissolved oxygen levels both in the water column and near the bottom of the reservoir.

For the benthic macroinvertebrate and fish community indicators, scoring criteria were developed based on statistical examination of two or more years of data. For these indicators, all data for a selected community characteristic (e.g., number of taxa) were ranked and trisected with the top one-third of the possible values representing the range for good conditions and the bottom onethird representing the range for poor conditions. Subsequent results are then compared to these ranges. This is an acceptable approach if the data base is sufficiently large and if it can be safely assumed that the data base covers the full spectrum of good to poor conditions.

The sediment quality indicator scoring criteria uses a combination of approaches. As will be seen in the description below, one component (sediment toxicity) is based on a subjective approach and the other (sediment chemistry) is based largely on published guidelines.

Each of the five aquatic health indicators are discussed below along with the rationale used to arrive at a score for each health indicator.

\subsubsection{Dissolved Oxygen (DO) Rating Scheme}

Oxygen is vital for life. In situations where funding is quite limited and only one indicator of reservoir health could be measured, dissolved oxygen (DO) would likely be that indicator. Hutchinson (1975) states that you probably can learn more about the nature of a lake from a series of oxygen measurements than from any other kind of chemical data. The presence, absence, and levels of DO in a lake or reservoir both control and are controlled by many physical, chemical, and biological processes (e.g., photosynthesis, respiration, oxidationreduction reactions, bacterial decomposition, DO saturation, etc.). DO maasurements coupled with observations of water clarity (Secchi depth), 
temperature, nutrients, and some basic hydrologic and morphometric information provide meaningful insight into the ecological health of a reservoir.

Ideally, a reservoir has near saturation concentrations of DO available to fish, insects, and zooplankton for respiration throughout the water column. This is usually the case during winter and spring, when most reservoirs are well mixed. However, with the onset of summer (typically characterized by more available sunlight, warmer water temperatures, and lower streamflows) both thermal stratification and increased biological activity combine to produce a greater biochemical demand for oxygen than is available, particularly at the bottom of the water column. As a result, low levels of DO often are observed under these conditions in the metalimnion and hypolimnion. Hypolimnetic and metalimnetic oxygen depletion are common, but undesirable occurrences, in many reservoirs. Not only do lower concentrations of DO in the water column affect the assimilative capacity of a reservoir, but if low enough and/or sustained long enough they adversely affect the health of the fish and benthic communities.

This ecological health evaluation considers oxygen concentrations in both the water column $\left(W_{D O}\right)$ and near the bottom of the reservoir $\left(B_{D O}\right)$. The final DO score or rating (ranging from 1 to 5 ) is the average of these two ratings:

DO Rating $=0.5\left(W_{D O}\right.$ rating $+B_{D O}$ rating $)$, where:

WC $_{D O}$ (Water Column DO) Rating--Isopleths of DO concentrations versus depth and time are plotted for each location during the period when maximum thermal stratification and hypolimnetic anoxia would be expected to occur. For run-ofthe-river reservoirs this period is about the beginning of April through the end of September, and for tributary reservoirs this period begins at about the same time but generally lasts through the end of October (examples provided in figure 2). 


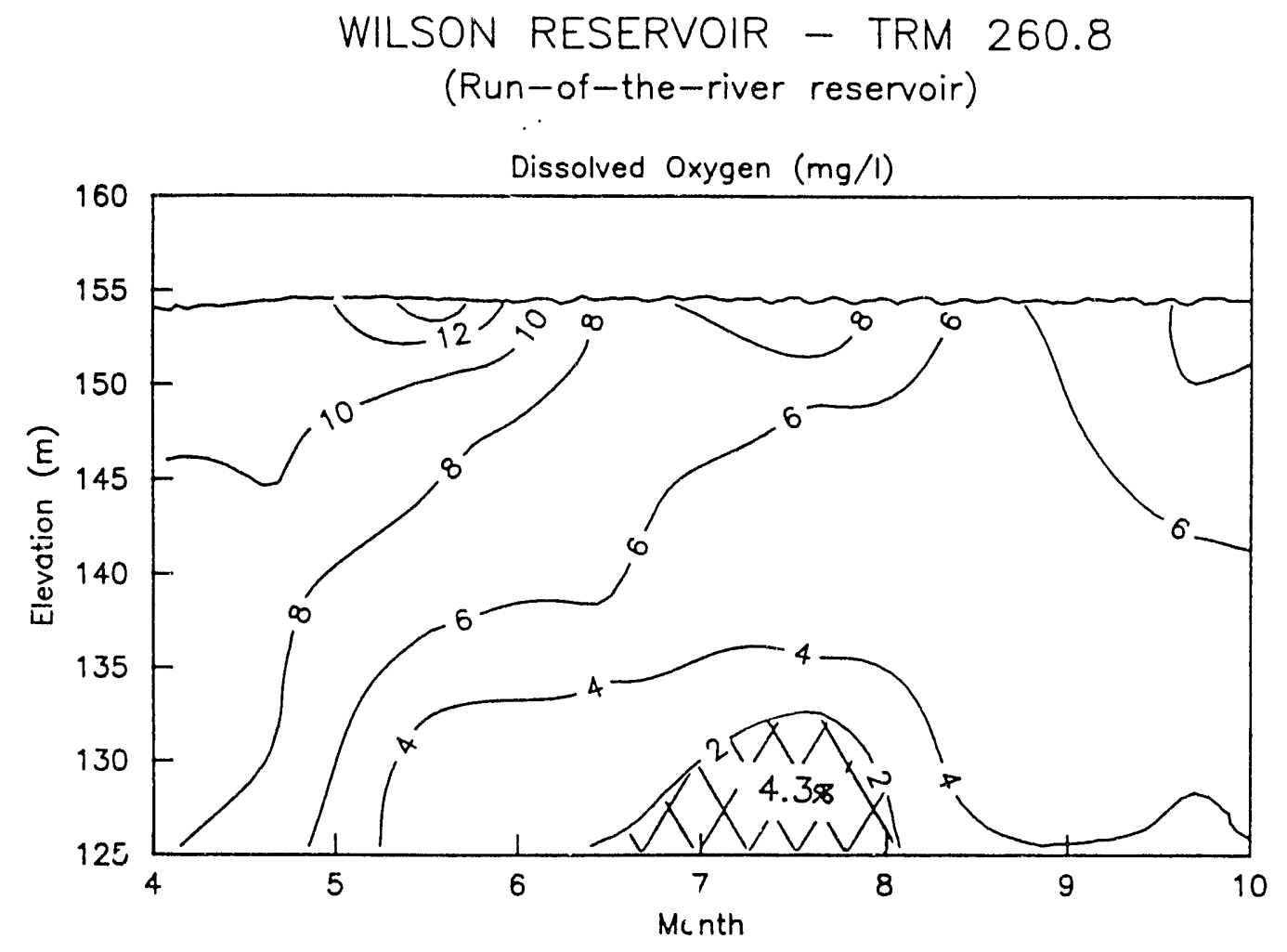

CHEROKEE RESERVOIR - HORM 76.0 (Tributary, storage reservoir)

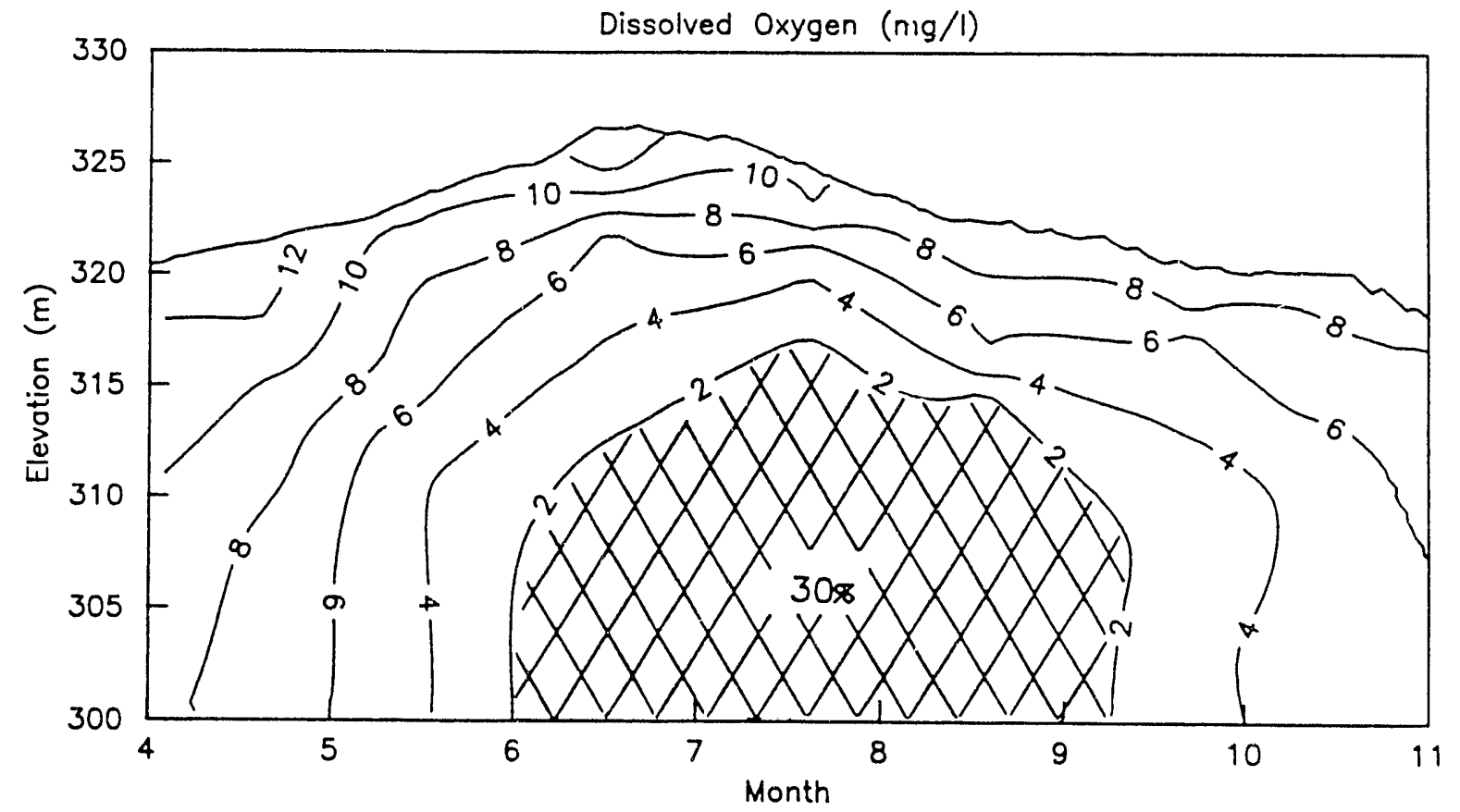

Figure 2. Time vs. Depth Plots of Dissolved oxygen Concentrations 
A concentration of $2 \mathrm{mg} / \mathrm{L}$ was selected as a level below which undesirable ecological conditions would exist, primarily adverse impacts to benthic macroinvertebrate organisms and loss of quality habitat. Fish also were considered in this decision. Their mobility, which allows them to avoid undesirable conditions made direct impact to benthos and loss of quality habitat for both benthos and fish the primary considerations. Historic information for TVA reservoirs indicated that the burrowing mayfly (Hexagenia sp.) disappears from the benthic community at DO concentrations of $2 \mathrm{mg} / \mathrm{L}$ and below (Masters and McDonough, 1993). Most fish species also avoid areas with Do concentration this low (loss of habitat), fish growth is reduced at these levels, and many highly desirable species such as sauger and walleye simply cannot survive at such low levels of DO.

Consequently, the $W_{D O}$ rating for each sample location is based on analysis of the percent of the time $x$ depth profile that the concentration of DO was less than $2.0 \mathrm{mg} / \mathrm{L}$ as shown below:

\section{Percent of [time $x$ depth] less than $2 \mathrm{mg} / \mathrm{L}$}

$$
\begin{aligned}
& <5 \% \\
& >10 \% \\
& \text { but } \leq 10 \%
\end{aligned}
$$

$$
\begin{aligned}
& \text { WC Roting for } \\
& \text { Sampling Location }
\end{aligned}
$$

5 (good);

3 (fair);

1 (poor).

Because most state DO water quality criteria for fish and aquatic life specify a minimum of $5.0 \mathrm{mg} / \mathrm{L}$ DO at the 1.5 meter ( 5 foot) depth, the $W_{D O}$ rating is lowered if the measured DO at the 1.5 meter depth at a sampling location was below $5.0 \mathrm{mg} / \mathrm{L}$ at any time. These adjustments are as follows:

\section{Minimum DO at} 1.5 meter depth

$<5.0 \mathrm{mg} / \mathrm{L}$

$<4.0 \mathrm{mg} / \mathrm{L}$

$<3.0 \mathrm{mg} / \mathrm{L}$ etc.
Sampling Location $W_{\text {DO }}$ Rating Change

Decreased one unit (e.g., 5 to 4);

Decreased two units;

Decreased three units; and 
Efforts are continuing to improve the method used to assess water column DO. One method being explored is to include the cross-sectional area of a sample location in the assessment. The monthly DO measurements made in the midchannel at a sample location would be assumed to be representative of the full width and superimposed on the cross-section of the reservoir at that location. Then the proportion of the total cross-sectional area with DO concentration less than $2.0 \mathrm{mg} / \mathrm{L}$ would be determined for each month. Percentages would then be averaged over the number of months for which data are collected (e.g., April-October).

This method would tend to improve DO ratings in deep, narrow reservoirs because the cross-sectional area of bottom water low in DO is small relative to the cross-sectional area of overlying water with adequate Do concentrations. This is potentially a bias in the currently used procedure.

$\mathrm{B}_{D O}$ (Bottom DO) Rating--Another common but undesirable occurrence in many development of near bottom anoxia caused by sediment oxygen demands. Sustained low DO concentrations near the bottom not only adversely impact the health of aquatic $1 \mathrm{ife}$ but also promote release of ammonia and dissolved metals into the interstitial pore an' near bottom water. If this phenomenon persists long enough, it can result in chronic and/or acute toxicity to bottom-dwelling animals. The $B_{D O}$ rating is based on an estimate of the number of months near bottom DO was less than $2 \mathrm{mg} / \mathrm{L}$, as follows:

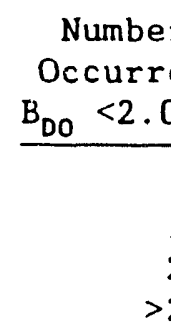

$$
\begin{aligned}
& \text { Length of } \\
& \text { time less } \\
& \text { than } 2 \mathrm{mg} / \mathrm{L}
\end{aligned}
$$

Less than one month One to two months Two or more months
Sampling Location

$B_{D O}$ Rating

In addition, if anoxic conditions (i.e., $0 \mathrm{mg} / \mathrm{L}$ ) are observed near the bottom at a location, the $B_{D O}$ rating is lowered one unit, with a minimum rating of 1 . 


\subsubsection{Chlorophyl1-a Rating Scheme}

Algae are the base of the aquatic food chain. Consequently, measuring algal biomass or primary productivity is important in evaluating ecological health. Without algie converting sunlight energy, carbon dioxide, and nutrients into oxygen and new plant material, a lake or reservoir could not support other aquatic life. Chlorophyll-a is a simple, long-standing, and well-accepted measurement for estimating algal biomass, algal productivity, and trophic condition of a lake or reservoir (Carlson, 1977). Too little primary productivity (e.g., mean summer chlorophyll-a concentrations less than 3 ug/L) indicates an inability to sustain a well fed, growing, balanced, and healthy aquatic community, eventually resulting in low standing stocks of fish. Too much primary productivity (e.g., mean summer concentrations greater than $15 \mathrm{ug} / \mathrm{L})$, evidenced by occasional dense algal blooms, poor water clarity, and the predominance of noxious blue-green algae, indicates poor ecological health. The large amounts of algal plant material produced under these conditions also deplete oxygen concentrations as the algae die and decomposed. This can cause or aggravate problems of low DO in bottom waters.

Scoring criteria for chlorophyll-a are based on the average of monthly samples collected from April through September (or October). Chlorophyll-a is rated as follows:

$$
\begin{gathered}
\text { Average Chlorophyll-a } \\
\text { Concentration }
\end{gathered}
$$

Less than $3 \mathrm{ug} / \mathrm{L}$

3 to $10 \mathrm{ug} / \mathrm{L}$

10.1 to $15 \mathrm{ug} / \mathrm{L}$

Greater than $15 \mathrm{ug} / \mathrm{L}$
Sampling Location Chlorophyll - a Rating

$$
\begin{aligned}
& 3 \text { (fair); } \\
& 5 \text { (good); } \\
& 3 \text { (fair); and, } \\
& 1 \text { (poor). }
\end{aligned}
$$

* If any single chlorophyll-a sample exceeds $30 \mathrm{ug} / \mathrm{L}$, the value is not included in calculating the average, but the rating is decreased one unit.

* If nutrients are present (e.g., total phosphorus greater than about $0.01 \mathrm{mg} / \mathrm{L}$ and nitrate+nitrite greater than about $0.05 \mathrm{mg} / \mathrm{L}$ ) but chlorophyll-a concentrations are generally low $(\mathrm{e} \cdot \mathrm{g} \cdot, \leq 3 \mathrm{ug} / \mathrm{L})$, another/other limiting or inhibiting factor such as toxicity must be considered. When these conditions exist, chlorophyll-a is rated 1 (poor). 


\subsubsection{Sediment Quality Rating Scheme}

Contaminated bottom sediments can have direct adverse impacts on bottom auna. Contaminated sediments can of ten be long-term sources of toxic substances to the aquatic environment. They may impact wildlife and humans through the consumption of contaminated food or water or through direct contact. These impacts may occur even though the water above the sediments meets water quality criteria. There are many sediment assessment methods, but there simply is no single method that measures all contaminated sediment impacts at all times and to all biological organisms (EPA, 1992). TVA's approach combines two sediment assessment methods--one biological, the other chemical--to evaluate reservoir sediment quality. TVA's scoring criterion is based on ratings for the toxicity of sediment pore water $\left(S_{T O X}\right)$ to test organisms, and the chemical analysis of sediment $\left(\mathrm{S}_{\mathrm{CHM}}\right)$ for heavy metals, organochlorine pesticides, and un-ionized ammonia. The final sediment quality score or rating is the average of these two ratings:

Sediment Quality Rating $=0.5$ ( $\mathrm{S}_{\text {TOX }}$ rating $+\mathrm{S}_{\text {CHM }}$ rating), where:

$\mathrm{S}_{\text {TOX }}$ (Sediment Toxicity) Rating--Reservoir sediment toxicity is evaluated using acute time-frame Microtox (light emitting bacteria) and Rotox (rotifer, Brachionus calyciflorus survival) tests. Microtox ${ }^{\otimes}$ and Rotox acute toxicity evaluations entail the exposure of these organisms to interstitial pore water from reservoir sediment. Microtox analysis evaluates the effective concentration in laboratory duplicate samples at which the light output is reduced by 10 percent relative to a control $\left(E_{10}\right)$. Microtox $\mathrm{EC}_{10}$ values measured in the laboratory have been shown to correspond with impairments to insect populations. However, use of Microtox to describe sediment toxicity in reservoirs is considered experimental. For this reason, Microtox results are 
not considered definitive by themselves. Consequently, rotifer acute toxicity tests (24-hour exposure) are also used. Rotifer toxicity is based on the average survival in three replicate samples. If average survival is significantly reduced ( 95 percent probability) from a control, the sample is considered to be toxic. Reservoir sampling locations were rated as follows:

Sediment Toxicity

No Significant rotifer toxicity and Microtox $\mathrm{EC}_{10}<25 \%$ and Microtox $\mathrm{EC}_{10}>25 \%$

Significant rotifer toxicity

\section{Sampling Location}

$\mathrm{S}_{\text {TOX }}$ Rating

$5($ good $)$

3 (fair);

1 (poor);

Note: Microtox will be replaced with acute (48-hour) Ceriodaphnia tests in subsequent monitoring efforts.

$S_{\text {CHM }}$ (Sediment Chemistry) Rating--Splits of the same sediment used in the sediment toxicity testing were analyzed for several heavy metals, organochlorine pesticides, and PCBs (table 1). Ratings for chemical sediment quality were based on the following--(1) detectable amounts of any organochlorine pesticide or PCB, (2) un-ionized ammonia concentrations in pore water above 200 ug $\mathrm{NH}_{3} / \mathrm{L}$, or (3) concentrations of heavy metals ( $\mathrm{Cd}, \mathrm{Cr}, \mathrm{Cu}, \mathrm{Hg}, \mathrm{Ni}, \mathrm{Pb}$, and $\mathrm{Zn}$ ) that exceed EPA Region V guidelines for heavily polluted freshwater sediment (EPA, 1977); where:

\section{Sediment Chemistry}

No constituents exceeding guidelines One constituent exceeding guidelines Two or more exceeding guidelines

\section{Sampling Location}

$\mathrm{S}_{\text {CHM }}$ Rating
5 (good);
3 (fair);
1 (poor).

* Constituents (organochlorine pesticides, PCBs, ammonia, and heavy metals) and guidelines are listed in table 1. 


\subsubsection{Benthic Community Rating Scheme}

The six community characteristics listed below were selected to evaluate the health of the benthic macroinvertebrate community:

1. Taxa Richness--Defined as "apparently" different taxa present. An increase in total taxa or taxa richness is used to indicate better conditions than low taxa richness.

2. Longed-Lived species--Defined as the number of taxa (Corbicula, Hexagenia, mussels, and snails) present that include individuals age $1+$ years (excludes Corbicula $<10 \mathrm{~mm}$ and Hexagenia $<20 \mathrm{~mm}$ ). These organisms are long-lived and their presence indicates conditions which allow long-term survival.

3. EPT--Defined as sum of "apparently" different taxa within these orders (Ephemeroptera-mayflies, Plecoptera-stoneflies, and Tricoptera-caddisflies). Higher numbers of this metric indicate good water quality conditions in streams. A similar use is incorporated here despite expected lower numbers in reservoirs than in streams.

4. Proportion as Chirononidae--Defined as the percent of the total organisms in the sample that were chironmids. A higher proportion indicates poor water quality conditions.

5. Proportion as Tubificidae--Defined as the percent of the total organisms present that were tubificids. A higher proportion indicates of poor water quality.

6. Proportion as Dominant Taxa--Defined as the percent of the total organisms present that were members of the dominant taxon. This is used as an evenness indicator, where a large proportion comprised by one or two taxa indicates poor conditions.

Given substantial habitat differences among forebays, transirion zones, and inflows, it was necessary to develop specific scoring criteria for these metrics for each area. Data handling also differed among the metrics. Metric 1 , taxa richness, was an average developed by dividing the sum of the total number of taxa in each sample by the total number of samples at that site. Metrics 2 and 3 were handled similarly. For metric 4 the proportion of chironomids in each sample was calculated, then this proportion was averaged for a location. An alternative that was considered was to sum the number of chironomids in all samples and divide by the sum of the total individuals for all samples. The 
approach selected gives equal weight to all samples regardless of sample size. This eliminates the bias introduced in the alternate approach when one sample at a site has an exceptionally large or small density. Metric 5 was calculated in the same way. Metric 6, proportion as dominant taxa, was calculated as a proportion for each sample, similar to computations for metrics 4 and 5 . The proportion was calculated for the dominant taxon in each sample even if the dominant taxon differed among the samples at a site. This allowed mere discretion to identify imbalances at a site than developing an average for a single dominant taxon for all samples at the site.

As stated at the beginning of section 3.1 , a quantitative approach was used to evaluate the benthic macroinvertebrate community information. Ti.e range of values for each of the six metrics found in the available data base (in this case, all the 1991 and 1992 monitoring data) served as the basis for evaluation criteria. For each metric at each of the three reservoir sampling zones (forebay, transition zone, and inflow) the range of the data base values is trisected into pror (lower-third of the values), fair (middle-third of the values), and good (top-third of the values). Results for each metric for the current year under evaluation are then compared to these ranjes and assigned quantitative values of 1 (poor), 3 (fair), or 5 (good) if they fall within the bottom-, middle-, or top-third, respectively. This results in a minimum score of 6 if all metrics at a site are poor, and a maximum score of 30 if all metrics are good. This was possible only on the run-of-the-river reservoirs; insufficient information was available to use this approach on invertebrate results from tributary, storage reservoirs. Detailed scoring criteria for each metric in ali three reservoit zones are provided in table 2.

Metrics were summed for each reservoir sampling : ite to yield a final benthic score and evaluated as follows: 
Benthic

Community

Score

6-10

11-15

16-20

21-25

26-30
Sampling Location

Rating

1 (poor)

2

3 (fair)

4

5 (good)

Note: If benthic community scores fall between $11-15$ or $21-25$, they are borderline and may be placed into one or the other three groups depending on professional judgment of the data set.

\subsubsection{Fish Community Rating Scheme}

A Reservoir Fish Assemblage Index (RFAI) developed by Jennings et. al. (in press), was used to rate fish communities. The RFAI is based on 11 metrics with scoring criteria specific to either run-of-the-river reservoirs or storage reservoirs. Scoring criteria also are specific for the type of sample location within those reservoirs--forebay, transition zone (or midreservoir), or inflow. The metrics address the following assemblage characteristics:

\section{Species Richness and Composition}

1. Total number of species--Greater numbers of species are considered representative of healthier aquatic ecosystems. As conditions degrade, numbers of species persisting at a site decline.

2. Number of sunfish species--Lepomid sunfish (excludes black basses, crapies, and rock bass) are basically invertivores, and high diversity of this group is indicative of reduced siltation and high sediment quality in littoral areas.

3. Number of sucker species--Suckers are also invertivores but inhabit the pelagic and more riverine sections. This metric closely parallels the migratory and lithophilic spawning species metrics (metrics 8 and 9) and may be deleted from future RFAI calculations.

4. Number of intolerant species--This group is made up of species that are particularly intolerant of habitat degradation. Higher densities of intolerant individuals represents better environmental quality.

5. Percentage of tolerant individuals sampled (excluding shad)--This metric signifies poorer water quality with increasing proportions of individuals tolerant of degraded conditions. 
Table 2. Scoring criteria for benthic macroinvertebrate metrics.

(run-of-the-river reservoirs)

\begin{tabular}{llcc}
\hline & \multicolumn{3}{c}{ FOREBAY SCORES } \\
METRIC & 1 & 3 & 5 \\
& $\underline{\text { POOR }}$ & FAIR & $\underline{\text { GOOD }}$ \\
\# TAXA & $<4$ & & $\geq 6$ \\
LONG-LIVED SPECIES & $\leq 0.5$ & $4-5.9$ & $>1.5$ \\
EPT & $<0.3$ & $0.6-1.5$ & $>0.6$ \\
\% CHIRONOMIDAE & $>60$ & $0.3-0.6$ & $<40$ \\
\% TUBIFICIDAE & $>30$ & $40-60$ & $<10$ \\
\% DOMINANT TAXA & $\geq 60$ & $10-30$ & $<50$
\end{tabular}

METRIC

\# TAXA
LONG-LIVED SPECIES
EPT
$\%$ CHIRONOMIDAE
\% TUBIFICIDAE
\% DOMINANT TAXA

METRIC

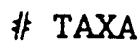

LONG-LIVED SPECIES

EPT

* CHIRONOMIDAE

$\%$ TUBIF ICIDAE

$z$ DOMINANT TAXA
1

POOR

$<4$

$\leq 0.6$

$<0.5$

$>40$

$>20$

$>70$

1

POOR

$<4$

$<1.0$

$\leq 0.2$

$>20$

$>10$

$>70$
TRANSITION ZONE SCORES FAIR

$4-7$

$0.7-1.6$

$0.5-0.8$

$20-40$

$10-20$

$50-70$
5

GOOD

$\geq 7$

$\geq 1.7$

$>0.8$

$<20$

$<10$

$<50$

\section{INFLOW SCORES}

\begin{tabular}{l}
3 \\
FAIR \\
\hline
\end{tabular}

5

$\underline{\text { COOD }}$

4-7

$1-1.5$

$0.3-1.0$

$\geq 7$

5-20

$2-10$

$50-70$

$>1.5$

$\geq 1.0$

$<5$

$<2$

$<50$ 


\section{Trophic Composition}

6. Percentage of individuals as omnivores--Omnivores are less sensitive to environmental stresses due to their ability to vary their diets. As trophic links are disrupted due to degraded conditions, specialist species such as invertivores decline while opportunistic omnivorous species increase in relative abundance.

7. Percentage of individuals as invertivores--Due to the special dietary requirements of this group of species and the limitations of their food source in degraded environments, proportion of invertivores increases with environmental quality.

\section{Reproductive Composition}

8. Number of migratory spawning species--Spawning requirements increase the vulnerability of some reservoir fish species. Migratory spawners need good water quality, low siltation, and adequate flows to successfully reproduce. Numbers of migratory spawning species will increase in reservoirs providing suitable conditions reflective of good environmental quality.

9. Number of lithophilic spawning species--Lithophilic broadcast spawners were selected due to their sensitivity to siltation. However, this metric has proven to be repetitive of the migratory spawners and number of sucker species metrics and its use will be discontinued or combined with migratory spawners in the future.

\section{Abundance and Fish Health}

10. Total number of individuals--This metric is based upon the assumption that high quality fish assemblages support large numbers of individuals (excluding shad).

11. Fish health assessment index--FHAI measures environmental stress on a top predator, the largemouth bass, based on rigorous external and internal examinations. The predicted negative correlation with environmental quality has not occurred over the four years of sampling. This may be due to the tolerant nature of the largemouth bass to poor water quality along with an overriding, more localized factor of the importance of food availability to bass health. Incidence of diseases, lesions, tumors, external parasites, deformities, and blindness will be noted for all fish collected and used in the future to replace the FHAI metric.

Note: Table 3 lists trophic, reproductive, and tolerance designations of fish species collected during this study.

Each metric is assigned a score of 1,3 , or 5 with 5 representing a "good" condition, and scores of 3 and 1 indicating "fair" and "poor" conditions, respectively. In cases where inadequate numbers of largemourh bass are sampled 
Table 3.

Core fish species list with trophic, tolerance, and reproductive designations (*) for use in preliminary electrofishing Reservoir Fish Assemblage Index (RFAI) for TVA reservoirs, 1991.

Trophic Guild
Species

rolerance

Chestnut lamprey

Spotted gar

Longnose gar

Shor tnose gar

Bowf in

American eel

Skipjack herring

Gizzard shad

Threadfin shad

Mooneye

Chain pickerel

Central stoneroller

Goldfish

Common carp

silver chub

Golden shiner

Emerald shiner

Ghost shiner

Spotfin shiner

Mimic shiner

Steelcolor shiner

Pugnose minnow

Bluntnose minnow

Fathead minnow

Bull head minnow

River carpsucker

Quill lback

Nor thern hog sucker

Smal Imouth buffalo

$B$ igmouth buffalo

Black buffalo

Spotted sucker

silver redhorse

Shor thead redhorse

River redhorse

Black redhorse

Golden redhorse

Blue catfish

Black but lhead

Yell ow bull thead

Brown bul thead

Channel catfish

Flathead catfish

Blackstripe topminnow

Blackspotted topminnow

Mosquit tof ish

Brook silverside

White bass

Yellow bass

Rock bass

Redbreast sunfish

Green sunf ish

Warmouth

Orangespotted sunf ish

Bluegill

Longear sunfish

Redear sunfish

Spot ted sunfish

Small mouth bass

Spotted bass

Largemouth bass

White crappie

Black crappie

Yellow perch

Logperch

Sauger

Walleye

Freshwater drum
Migratory Spawner

Lithophilic Spawner
M

TOL

TOL

INT

M

$L$

TOL

TOL

TOL

INT

INT

INT

TOL

TOL

TOL

INT

TOL

INT

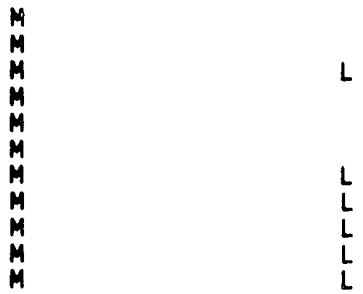

$M$

L

-Designations:

Trophic: herbivore (HB), parasitic (PS), Planktivore (PL), omivore (OM), insectivore (IN), piscivore (PI),
specialized benthic insectivore (SP)

Tolerance:

tolerant (TOL), intolerant (INT)

Migratory spawning species (M)

Lithophilic spawning species (L) 
to calculate the FHAI, a score of 3 is arbitrarily assigned to the FHAI metric. As stated above, different scoring criteria were developed for each metric for run-of-the-river and tributary reservoirs due to the distinct habitat differences and the differences in fish assemblages they support. Scoring criteria by reservoir type and zone are listed in table 4.

Scores of the 11 metrics were summed to produce preliminary electrofishing RFAI values for each of three distinct sampling zones per reservoir. The range of 'attainable' RFAI values (11 to 55) was divided into five equal groips for the most recent (1992) sampling results.

The 1992 RFAI ratings for reservoir sampling locations are as follows:

RFAI

Score

$11-19$

20-28

29-37

38-45

$46-55$
Sampling Location Rating

1 (poor)

2

3 (fair)

4

5 (good)

Note: If RFAI scores fall between 20-28 or 38-45, they are considered borderline and may be placed into one or the other three groups depending upon professional judgment of the data set.

If the FHAI, number of suckers, and number of lithophilic broadcast spawners are omitted, only eight metrics would be available. A minimum of ten metrics is desired to address the range of sensitivity necessary to accurately depict biological responses to environmental degradation. Efforts are continuing to include some measure of piscivores and an evaluation of forage abundance (primarily shad) in the existing metrics or to develop new metrics for these community characteristics. It is anticipated that additional metrics addressing pelagic communities will be included in the near future based upon gill netting results. 
Table 4.

Reservoir Fish Assemblage Index metrics and scoring criteria developed for TVA run-of-the-river and tributary reservoirs. Scoring reflects relative fish community quality, with a score of 5 representing highest quality, and a score of 1 the poorest.

RUNOF-THERNER

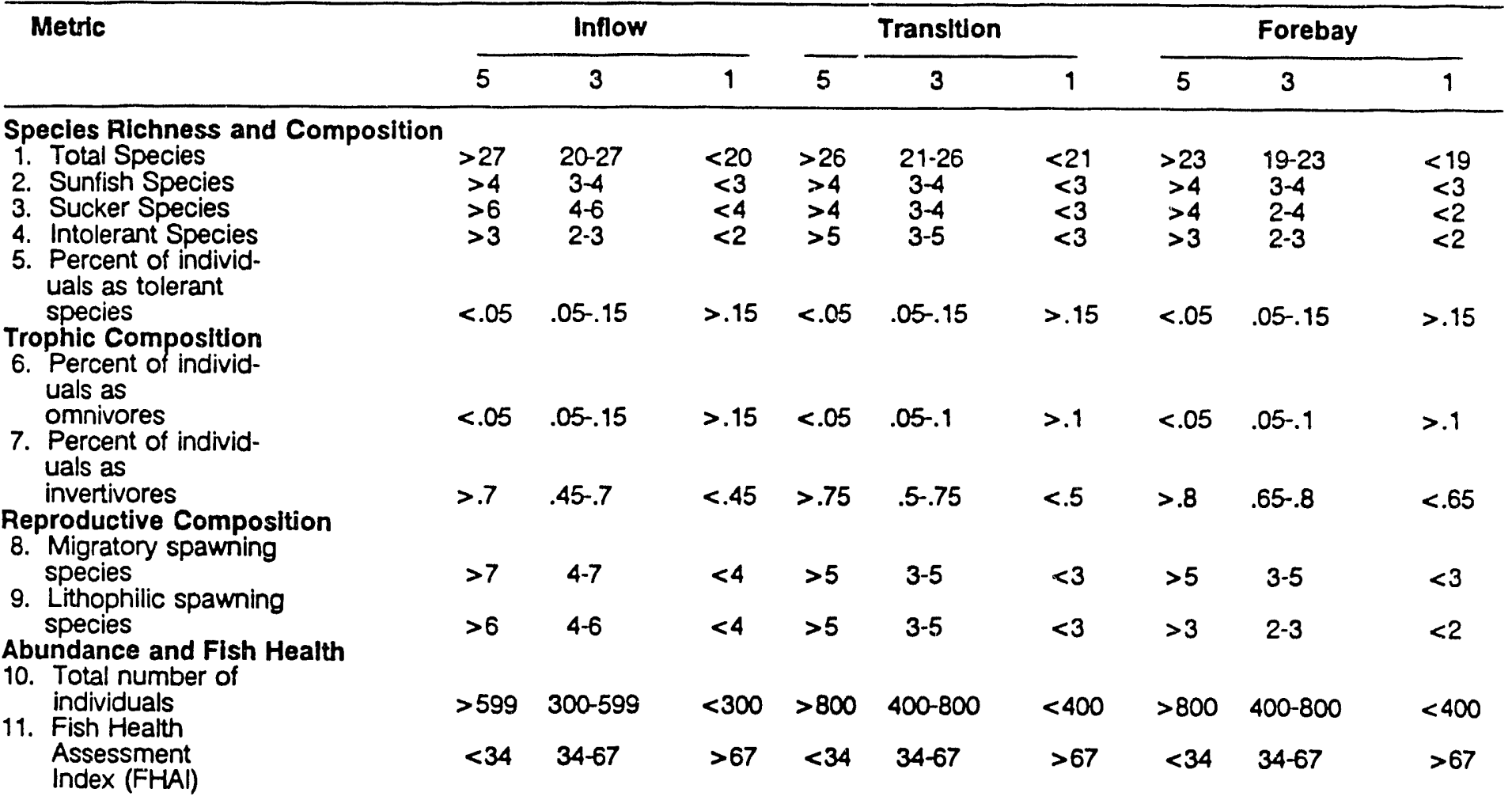

\section{TRIBUTARY}

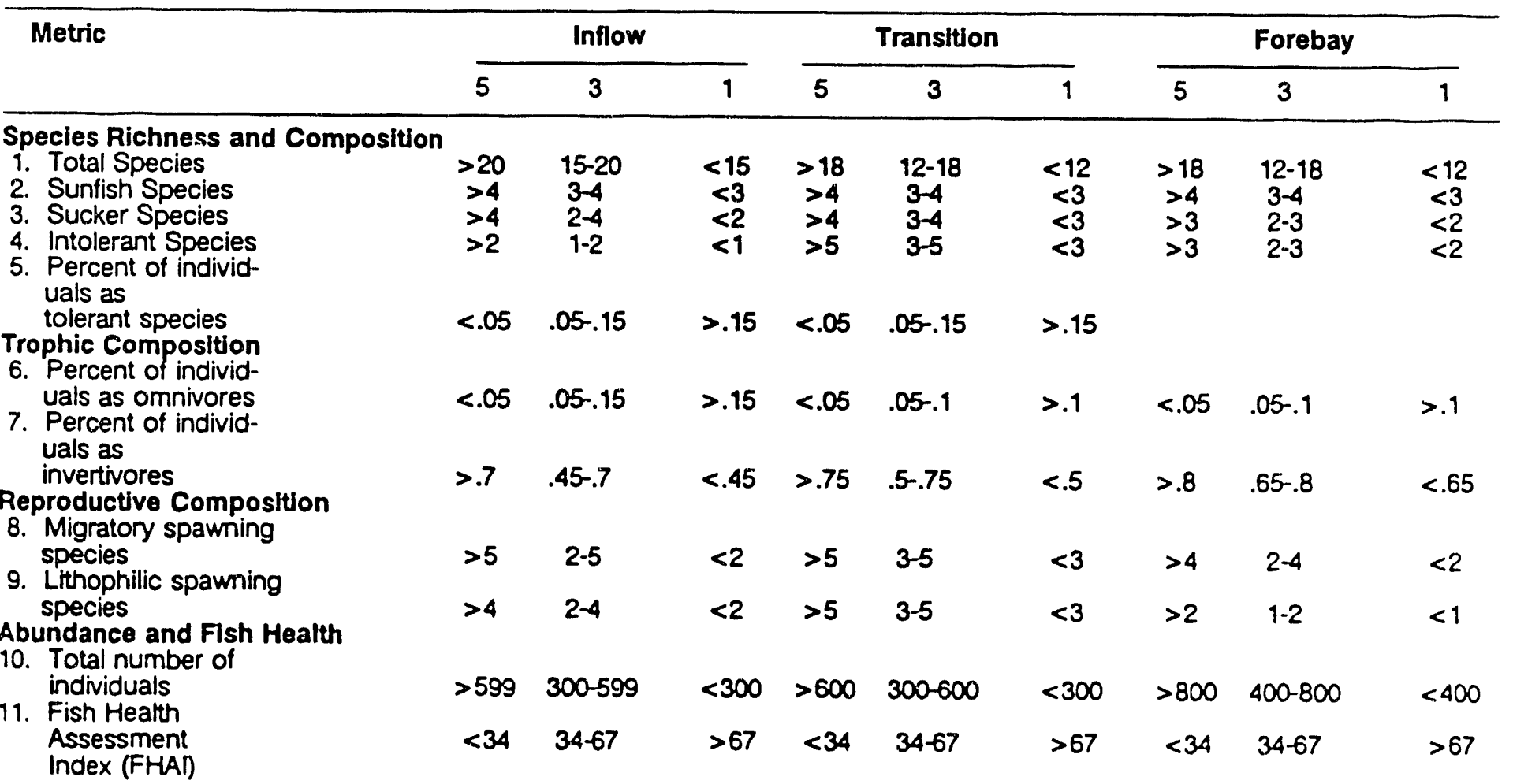




\subsubsection{Qverall Reservoir Health Determination}

The overall ecological health of a reservoir is determined by summing the numeric results (ranging from 5 representing good conditions to 1 representing poor) for the five indicators (DO, chlorophyll, sediment quality, benthos, and fish community) for each location. Each reservoir has one to four saiple locations depending on reservoir size and shape. Location sums are totaled and that sum divided by the maximum possible score. Thus, the possible range of scores is 20 percent (all metrics poor) to 100 percent (all metrics good).

During the development of this evaluation process it was necessary to divide the final scoring range (20-100 percent) into categories representing good, fair, and poor conditions. This was achieved as follows:

1. Results were plotted and examined for apparent groupings.

2. Groupings were then compared to known, a priori conditions (focusing on reservoirs with known poor conditions) and necessary adjustments were made.

3. The three groupings were compared to a trisection of the overall scoring range. A scoring range was adjusted up or down a few percentage points to ensure a reservoir with known conditions fell within the appropriate category. This was done only in circumstances where a nominal adjustment was necessary.

The final scoring ranges for 1992 information are as follows:

$\begin{array}{llll} & \text { Poor } & \text { Fair } & \text { Good } \\ \text { Run-of-the-river reservoirs } & \leq 52 \% & >52-72 \% & >72 \% \\ \text { Storage reservoirs } & \leq 56 \% & >56-72 \% & >72 \%\end{array}$

The difference in the poor scoring range between the two types of reservoirs was due to item 2 above. Two storage reservoirs with known poor conditions rated slightly higher than the lower (poor) grouping. Hence, the high end of the lower scoring range for storage reservoirs was shifted upward to include these reservoirs ( 56 percent). 
Based on the experience gained in developing this evaluation process, feedback from other state and federal professionals upon their review of this evaluation process, and another year of information, slight modifications were made in the original evaluation process and the numerical scoring criteria for each of the five ecological health indicators. An example of the calculations and final categorization of good, fair, or poor conditions for a run-of-the-river reservoir and a storage reservoir for the most recent information (1992) are illustrated in table 5 .

This ecological health evaluation system has proven to be a useful tool. It allows funneling a large amount of data into single index values which can be compared among reservoirs or used to evaluate year-to-year changes for individual reservoirs. The index effectively separates the reservoirs into the three categories of good, fair, and poor. For 1992 results, scores for the 11 run-ofriver reservoirs ranged from 48 percent to 88 percent. Six reservoirs rated good, four fair, and one poor. Scores for the 12 deep storage reservoirs that were monitored ranged from 53 percent to 73 percent. Only one reservoir rated good, seven fair, and four poor.

Index results have not yielded any "big" surprises--ratings for most reservoirs have fallen within expected categories. Similar results were observed in both 1991 and 1992, primarily due to similar weather conditions and reservoir flows those two years. This indicates that the evaluation system is likely to yield consistent results for similar ecological conditions.

Interestingly, one of the storage reservoirs showed a substantial improvement in ecological health between 1991 (poor, 53 percent) and 1992 (fair, 64 percent). This particular reservoir is downstream of a site where a weir was 
Table 5. Computational Method For Evaluation of Reservoir Health

Wilson Reservoir - 1992 (Run-of-the-river reservoir)

\begin{tabular}{|c|c|c|c|c|c|c|}
\hline \multirow[t]{2}{*}{ Aquatic Health Indicator } & \multicolumn{3}{|c|}{ Observations } & \multicolumn{3}{|c|}{ Ratings } \\
\hline & Forebay & $\begin{array}{c}\text { Transition } \\
\text { zone }\end{array}$ & Inflow & Forebay & $\begin{array}{l}\text { Transition } \\
\text { Zone }\end{array}$ & Inflow \\
\hline $\begin{array}{l}\text { Dissolved Oxygen: } \\
x \text { of [time } x \text { depth] }<2 \mathrm{mg} / \mathrm{l} \\
\text { less than } 5 \mathrm{mg} / 1 \text { at } 1.5 \mathrm{~meter} \\
\text { \# months }<2 \mathrm{mg} / 1 \text { at bottom }\end{array}$ & $\begin{array}{l}4.3(5) \\
\text { No } \\
1(2)^{\star}\end{array}$ & $\begin{array}{c}\text { No Samples } \\
\text { : } \\
-\end{array}$ & $\begin{array}{l}0(5) \\
\text { No } \\
0(5)\end{array}$ & *DO was & $\mathrm{mg} / \mathrm{l}$ at the & bottom \\
\hline $\begin{array}{l}\text { Sediment Quality } \\
\text { Rotifer Survival } \\
\text { Microtox (EC10) } \\
\text { Metals/NH3/pesticides }\end{array}$ & $\begin{array}{l}97 \%(5) \\
28 \% \\
\text { None (5) }\end{array}$ & $\begin{array}{c}\text { No Samples } \\
- \\
- \\
-\end{array}$ & $\begin{array}{c}\text { No Samples } \\
- \\
- \\
-\end{array}$ & 5 & - & $\cdot$ \\
\hline $\begin{array}{l}\text { Benthic Community: } \\
\text { Dominance } \\
\text { Tubificidae } \\
\text { Chironmidae } \\
\text { EPT } \\
\text { Long-lived } \\
\text { Taxa richness } \quad \text { Total }\end{array}$ & $\begin{array}{l}1 \\
1 \\
1 \\
1 \\
1 \\
3 \\
8\end{array}$ & No Samples & $\begin{array}{r}5 \\
1 \\
3 \\
5 \\
5 \\
5 \\
24\end{array}$ & 1 & - & 4 \\
\hline $\begin{array}{l}\text { Fish Community: } \\
\text { RFCI score }\end{array}$ & 33 & No Samples & 41 & 3 & $\cdot$ & 4 \\
\hline \multirow{3}{*}{\multicolumn{2}{|c|}{$\begin{array}{l}\text { Overall Reservoir Evaluation Key: } \\
\text { Less than } 52 \% \text { - poor (red) } \\
>52 \% \text { and }<72 \% \text { - fair (yellow) } \\
\text { Greater than } 72 \% \text { - good (green) }\end{array}$}} & \multicolumn{2}{|c|}{ Sampling Location Sum } & 14 of 25 & & 13 of 15 \\
\hline & & \multicolumn{2}{|c|}{ Reservoir Sum } & \multicolumn{3}{|c|}{27 of $40 \quad[68 \%]$} \\
\hline & & \multicolumn{3}{|c|}{ OVERALL RESERVOIR EVALUATION } & "fair" (yellow) & \\
\hline
\end{tabular}

Cherokee Reservoir - 1992 (Tributary storage reservoir)

\begin{tabular}{|c|c|c|c|c|c|c|}
\hline \multirow[t]{2}{*}{ Aquatic Health Indicator } & \multicolumn{3}{|c|}{ Observations } & \multicolumn{3}{|c|}{ Ratings } \\
\hline & Forebay & $\begin{array}{l}\text { Mid- } \\
\text { reservoir }\end{array}$ & Inflow & Forebay & $\begin{array}{l}\text { Mid- } \\
\text { reservoir }\end{array}$ & Inflow \\
\hline $\begin{array}{l}\text { Dissolved Oxygen: } \\
\% \text { of [time } x \text { depth] }<2 \mathrm{mg} / \mathrm{l} \\
\text { less than } 5 \mathrm{mg} / 1 \text { at } 1.5 \mathrm{~meter} \\
\text { \#onths }<2 \mathrm{mg} / \mathrm{l} \text { at bottom }\end{array}$ & $\begin{array}{l}31.6(1) \\
\text { No } \\
3(1) \star\end{array}$ & $\begin{array}{l}30.0(1) \\
\text { No } \\
3(1) \star\end{array}$ & $\begin{array}{c}\text { No Samples } \\
- \\
- \\
-\end{array}$ & 1 & $\mathrm{mg} / \mathrm{l}$ at the & bottom \\
\hline $\begin{array}{l}\text { Chlorophyll-a, ug/l: } \\
\text { average } \\
\text { maximum }\end{array}$ & $\begin{array}{r}9.0 \\
15.0\end{array}$ & $\begin{array}{l}11.5 \\
17.0\end{array}$ & No Samples & 5 & 3 & - \\
\hline $\begin{array}{l}\text { Sediment Quality } \\
\text { Rotifer Survival } \\
\text { Microtox (EC1O) } \\
\text { Metals/NH3/pesticides }\end{array}$ & $\begin{array}{l}100 \%(5) \\
53-57 \% \\
N H 3(3)\end{array}$ & $\begin{array}{c}100 \% \text { (5) } \\
65 \% \\
\mathrm{CU}, \mathrm{NH3} \text { (1) }\end{array}$ & $\begin{array}{c}\text { No Samples } \\
- \\
- \\
-\end{array}$ & 4 & 3 & - \\
\hline $\begin{array}{l}\text { Fish Community: } \\
\text { RFCl score }\end{array}$ & 29 & 25 & 27 & 3 & 2 & 2 \\
\hline \multirow{3}{*}{\multicolumn{2}{|c|}{$\begin{array}{l}\text { Overall Reservoir Evaluation Key: } \\
\text { Less than } 57 \% \text { - poor (red) } \\
>57 \% \text { and }<72 \% \text { - fair (yellow) } \\
\text { Greater than } 72 \% \text { - good (green) }\end{array}$}} & \multicolumn{2}{|c|}{ Sampling Location Sum } & 13 of 20 & 9 of 20 & 2 of 5 \\
\hline & & \multicolumn{2}{|c|}{ Reservoir Sum } & \multicolumn{3}{|c|}{24 of $45 \quad[53 \%]$} \\
\hline & & \multicolumn{3}{|c|}{ OVERALL RESERVOIR EVALUATION } & "poor" (red) & \\
\hline
\end{tabular}


being constructed in 1991 to improve dissolved oxygen in the releases of the next upstream reservoir. During that period, flows from the upstream reservoir were held to a minimum to facilitate weir construction activities. Construction was completed and flows returned to normal in 1992 causing improvements in DO levels (increases) and chlorophyll-a levels (decreases). These results indicate the evaluation system may be sufficiently dynamic to detect year-to-year differences. Final evaluation of this dimension of the ecological health evaluation system will occur in subsequent years as weather and flow conditions vary.

\subsection{Use Suitability}

\subsubsection{Bacteriological Sampling}

Among the seven Valley states there is no single set of bacteriological criteria for the evaluation of the suitability of water for water contact recreation. Each state has its own unique criteria for classification of waters for use for water contact recreation. To make comparisons uniform among the many locations, EPA guidelines for fecal coliform bacteria are applied to TVA results to determine use suitability for water contact recreation (EPA, 1991).

TVA's water contact recreation criteria using fecal coliform bacteria are as follows:

Fully Supporting water contact recreation:

a geometric mean of less than 200 colonies per $100 \mathrm{~mL}$ for spring and summer samples (the geometric mean is calculated based on at least ten individual samples, with samples collected at least 24-hours apart and within a 30-day period); and

- a single sample maximum of 400 colonies per $100 \mathrm{~mL}$ is exceeded in less than 10 percent of samples.

Partially Supporting water contact recreation:

a geometric mean of less than 200 colonies per $100 \mathrm{~mL}$ for spring and summer samples; and

- a single sample maximum of 400 colonies per $100 \mathrm{~mL}$ is exceeded in 11 to 25 percent of samples. 
Not Supporting water contact recreation:

- a geometric mean greater than 200 colonies per $100 \mathrm{~mL}$ for spring and summer samples; or

- a single sample maximum of 400 colonies per $100 \mathrm{~mL}$ is exceeded in more than 25 percent of samples.

TVA recommends no water contact recreation for at least two days following rain events at locations which only partially support water contact, because of the bacteria which are washed into the water. In addition, TVA recommends no water contact recreation in the immediate vicinity of wastewater discharges regardless of what fecal bacteria data show, because of the possibility of mechanical breakdowns and sewage bypasses or overflows.

\subsubsection{Fish Tissue Studies}

TVA and state agencies coordinate with one another in conducting fish tissue studies in the Tennessee Valley. There is a shared interest in the status of TVA reservoirs as important and valuable resources. State agencies are responsible for regulatory and public health decisions and are interested along with TVA in the ecological health of Valley reservoirs and knowing if $f$ ish from these reservoirs are safe to eat.

Prior to initiating sample collections each autumn, TVA and involved Valley state agencies meet to discuss the previous year's results and decide appropriate direction for further study. Agreements are reached on species to be examined, locations to be sampled, and the agencies responsible for conducting each part of the work. TVA provides to the appropriate states the results for that part of the work for which TVA has responsibility. The states then have the responsibility to take whatever action as they deem necessary to protect public 
health. This usually involves deciding whether or not to issue an advisory against consuming selected species or age classes of fish. TVA's role in this process is to provide accurate results, to provide consultation to the state(s) as appropriate, and honor the state's decisions. 


\subsection{REFERENCES}

Carlson, R. E. 1977. "A Trophic State Index for Lakes." Limnology and Oceanography, 22:361-369.

Environmental Protection Agency. 1992. Sediment Classification Methods Compendium." EPA 823-R-92-006, USEPA, Washington D.C., September 1992.

Environmental Protection Agency. 1991. "Guidelines for the Preparation of the 1992 State Water Quality Assessments (305(b) Reports)." USEPA, Washington D.C., August 1991.

Environmental Protection Agency. 1977. "Guidelines for the Pollutional Classification of Great Lakes Harbor Sediments." USEPA, Region V, Chicago, April 1977.

Hutchinson, G. Evelyn. 1975. A Treatise on Limnology, Volume 1, Part 2-Chemistry of Lakes, J. Wiley and Sons, New York.

Masters, A. and T. A. McDonough. 1993. TVA Water Resources, Chattanooga, TN, Personal Communication, April 1993. 

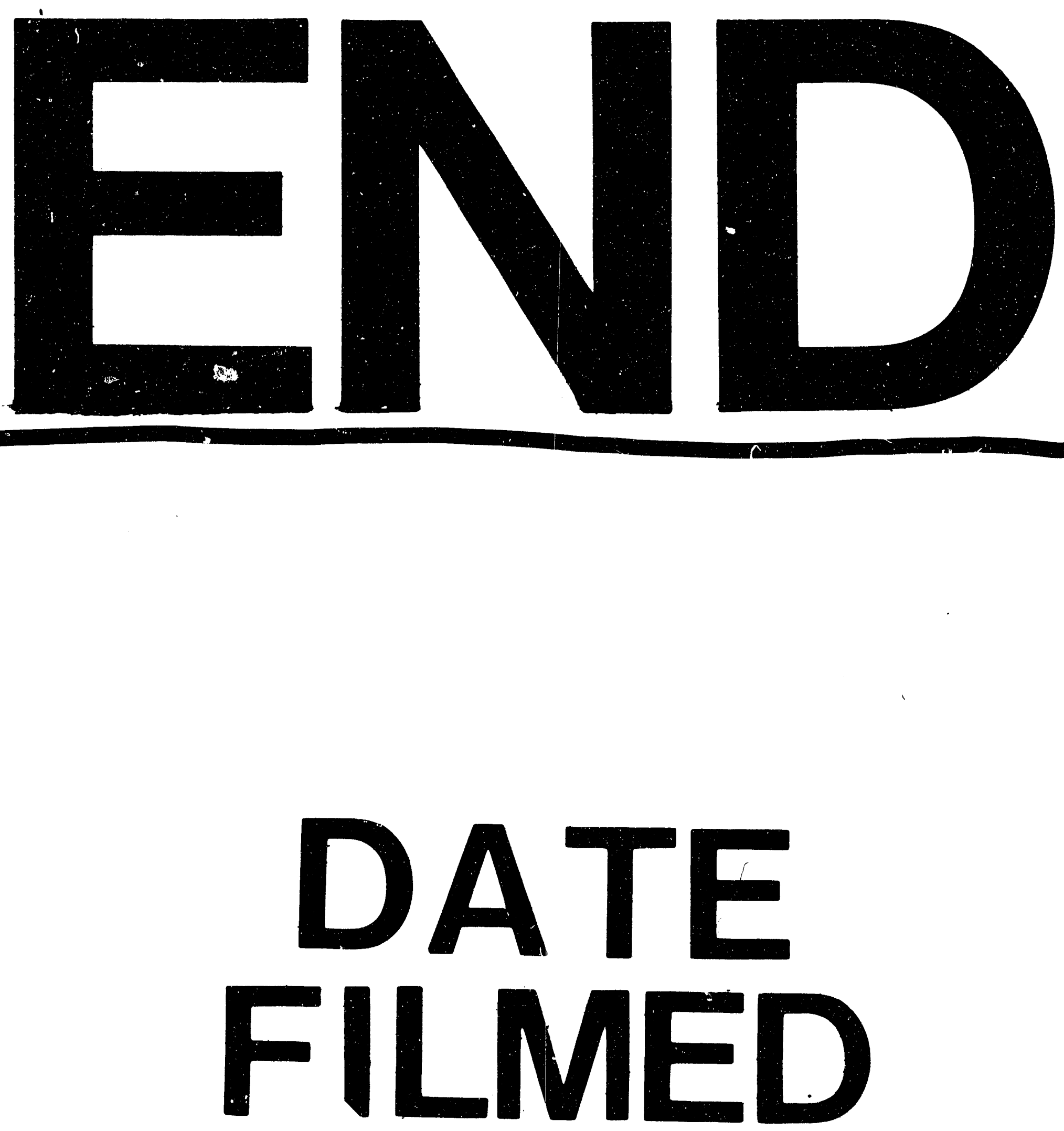

1

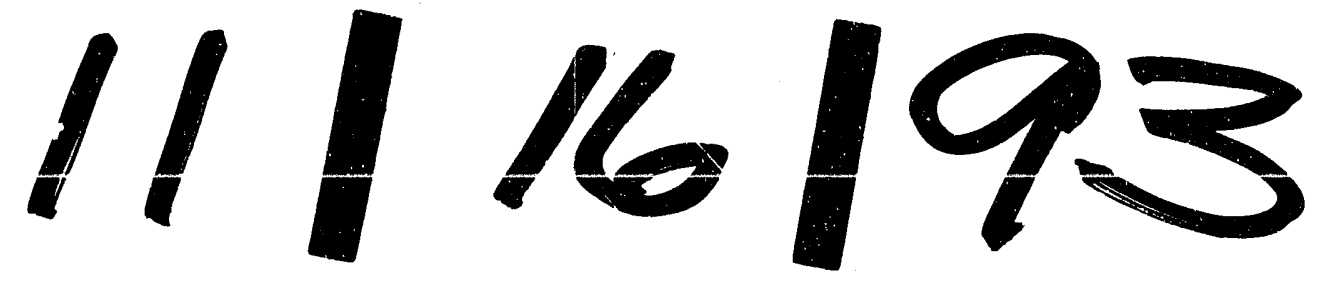




\section{.}

1 